\title{
SZANSE I ZAGROŻENIA ZARZĄDZANIA RÓŻNORODNOŚCIĄ W ŚWIECIE MIGRACJI
}

\section{Abstract \\ Opportunities and threats of managing diversity in the world of migrations}

The aim of the publication is to analyze the phenomenon of multiculturalism in the context of education of migrant children. In the last decades, especially in the European Union countries, a phenomenon of social stratification is caused by the migration crisis and the need to redefine social life and its important dimension - education. Managing diversity at school requires a series of organizational and systemic actions to facilitate the integration process. An important part of this process is the co-operation of directors, teachers, parents and the entire local community. In this article, we will examine the different aspects of the diversity management process at the school to which the migrant child attends.

Keywords: integration, diversity, multiculturalism, education

\section{Streszczenie}

Celem publikacji jest analiza zjawiska wielokulturowości w kontekście edukacji dzieci migranckich. W ostatnich dekadach zwłaszcza w krajach Unii Europejskiej mamy do czynienia ze zjawiskiem rozwarstwienia społecznego, które dyktowane jest kryzysem migracyjnym i koniecznością przedefiniowania życia społecznego i jego istotnego wymiaru - edukacji. Zarządzanie różnorodnością w szkole wymaga podjęcia wielu działań organizacyjnych i systemowych w celu ułatwienia procesu integracji. Ważnym elementem tego procesu jest współdziałanie dyrektorów, nauczycieli, rodziców i całej społeczności lokalnej. W artykule przeanalizowano poszczególne aspekty procesu zarządzania różnorodnością w szkole, do której uczęszcza dziecko migranckie.

Słowa kluczowe: integracja, różnorodność, wielokulturowość, edukacja 
Dynamiczne zmiany, jakie zachodzą we współczesnym świecie, są oznaką naszych czasów. Jeszcze nie tak dawno przeszliśmy od społeczeństw agrarnych skupionych na konformizmie, poprzez społeczeństwo industrialne do społeczeństwa opartego na wiedzy. Społeczeństwo przemysłowe jest zastępowane społeczeństwem informacyjnym, w którym informacja jest traktowana jako szczególne dobro niematerialne, równoważne lub cenniejsze nawet od dóbr materialnych, następnie przekształca się w społeczeństwo wiedzy, w którym podstawowym zasobem staje się właśnie wiedza, a kluczową rolę odgrywają edukacja, innowacja oraz kapitał intelektualny [Zachorowska-Mazurkiewicz, 2007]. Obecnie żyjemy w społeczeństwie, które opiera się na różnorodności - dającej możliwość poznania ,innych” i współistnienia w globalnym świecie. Wiek XXI wymaga dziś obywatelstwa skoncentrowanego na wrażliwości kulturowej i międzynarodowej, z orientacją raczej na przyszłość niż przeszłość. Wielokulturowość jest w dzisiejszych czasach nowym paradygmatem, który jest jednak niewłaściwie wykorzystywany i często bardzo źle rozumiany [Rosado, 2006: 1].

Warto odnieść się do próby zdefiniowania zjawiska wielokulturowości. Caleb Rosado wskazuje, że wielokulturowość to system zachowań i przekonań, który uznaje obecność wszystkich różnorodnych grup w społecznościach i organizacjach. Uznaje też ich wartości i różnice społeczno-kulturowe, zachęca do poznania i inkluzji oraz upowszechniania wartości multikulturowych [Rosado, 2006: 2]. Wartością społeczeństw multikulturowych jest edukacja, która pozwala spojrzeć na „innego”, poznać go. Powinna uczyć również szacunku i znoszenia barier, tak by „inny” stał się „,swój”.

Istotne jest przedefiniowanie dotychczasowych przekonań społecznych o równości grup wykluczanych w społeczeństwach. Najbardziej zagrożonymi grupami są kobiety, osoby z niepełnosprawnościami (szczególnie tymi widocznymi) czy osoby o innym kolorze skóry, wywodzące się z innych grup kulturowych, narodowych i etnicznych [Silver, 1995: 74-75; Szarfenberg, 2007]. Ryszard Szarfenberg wskazuje, że proces wykluczenia odbywa się m.in. przez niejednoznaczność pozycji społecznej i wynikającej stąd obcości, pozbawienie władzy i dostępu do podejmowania decyzji, mniejsze możliwości edukacyjne i zawodowe oraz większe narażenie na skutki społecznych nacisków i kryzysów gospodarczych [2007: 3]. Pisząc o różnorodności w edukacji, mamy na myśli dzieci ze specjalnymi potrzebami edukacyjnymi, dzieci uzdolnione, dzieci cudzoziemskie oraz dzieci polskie powracające $\mathrm{z}$ zagranicy, które $\mathrm{z}$ racji przynależności do mniejszości są zagrożone wykluczeniem społecznym i wymagają szczególnych działań ze strony opiekunów. Na potrzeby niniejszej publikacji analizie została poddana grupa dzieci imigranckich.

W dobie kryzysu migracyjnego na świecie rozumienie wielokulturowości, rozumienie ,innych”, z którymi przychodzi nam żyć i pracować, wymaga otwartości i zrozumienia. W ostatnich dekadach zwłaszcza w krajach Unii Europejskiej mamy do czynienia ze zjawiskiem rozwarstwienia społecznego, które dyktowane jest kryzysem migracyjnym i koniecznością przedefiniowania życia społecznego i jego istotnego wymiaru - edukacji. Szkoły i placówki oświatowe są zmuszone do radzenia sobie z coraz większym zróżnicowaniem wśród uczniów. Fakt ten 
jest szczególnie istotny dla edukacji, gdyż - jak podają statystyki demograficzne - dzieci w wieku szkolnym z rodzin imigranckich jest w krajach Unii Europejskiej od $6 \%$ do nawet ok. $33 \% \mathrm{w}$ systemach oświatowych ${ }^{1}$. W polskich szkołach przez lata obserwowaliśmy stałą liczbę dzieci cudzoziemskich i wynosiła ona około 1\% [Gmaj i in., 2013], współcześnie liczba dzieci imigranckich w polskich szkołach dynamicznie się zmienia [OECD, 2016]. Należy wskazać, że najwięcej dzieci cudzoziemskich uczy się w szkołach i przedszkolach w dużych miastach i w pobliżu ośrodków imigranckich. Istotną informacją jest również fakt, iż statystyki nie ujmują dzieci, których jedno z rodziców jest obcokrajowcem czy takich o nieunormowanym statusie prawnym. Innym ważnym aspektem w perspektywie edukacyjnej jest nauczanie dzieci z innych grup etnicznych, a będących obywatelami polskimi (m.in. Romowie, Kaszubi czy Łemkowie). Warto w tej sytuacji pamiętać, że uczniowie z tych grup wymagają nierzadko wsparcia bardziej kompleksowego, obejmującego całą rodzinę. Wysiłek, który gwarantuje sukces edukacyjny i społeczny tych dzieci, leży nie tylko po stronie ich samych czy ich rodzin, ale szczególnie w gestii państwa przyjmującego, dyrektorów szkół i placówek oświatowych, nauczycieli i całych społeczności.

\section{Uwarunkowania prawne edukacji dzieci migranckich w Polsce}

W tym miejscu warto odwołać się do preambuły Ustawy o systemie oświaty, w której odnaleźć możemy zapis mówiący o tym, że

kształcenie i wychowanie służy rozwijaniu u młodzieży poczucia odpowiedzialności, miłości ojczyzny oraz poszanowania dla polskiego dziedzictwa kulturowego, przy jednoczesnym otwarciu się na wartości kultur Europy i świata. Szkoła winna zapewnić każdemu uczniowi warunki niezbędne do jego rozwoju, przygotować go do wypełniania obowiązków rodzinnych i obywatelskich w oparciu o zasady solidarności, demokracji, tolerancji, sprawiedliwości i wolności [Preambuła Ustawy z dnia 7 września 1991 r. o systemie oświaty].

Należy również wskazać na konkretne zapisy regulujące sprawy edukacji dzieci migranckich. Najistotniejszy jest artykuł 94a Ustawy o systemie oświaty, który gwarantuje osobom niebędącym obywatelami polskimi prawo do nauki i opieki w przedszkolach i szkołach publicznych różnych typów na warunkach dotyczących obywateli polskich.

Warto w tym miejscu podkreślić prawo dzieci cudzoziemskich do nauki języka polskiego oraz do zajęć wyrównujących wiedzę. Każde dziecko niebędące obywatelem polskim ma prawo do dodatkowych bezpłatnych lekcji języka polskiego

${ }^{1}$ Najwięcej dzieci w wieku szkolnym obejmują systemy Niemiec, Austrii, Luksemburga czy Francji. Dane za: Eurydice Information on Education Systems and Policies in Europe, http://eacea. ec.europa.eu/education/eurydice/index_en.php [dostęp: 25.07.2017]. 
organizowanych w szkole, do której chodzi, przez okres 12 miesięcy, w wymiarze nie mniejszym niż dwie godziny lekcyjne tygodniowo. Ma również prawo do bezpłatnych zajęć wyrównujących, jednak wymiar zajęć dodatkowych z zajęć lekcji polskiego oraz lekcji wyrównawczych nie może być wyższy niż pięć godzin lekcyjnych tygodniowo. Zapis ten jest tym bardziej istotny, że dzieci migranckie $\mathrm{i}$ ich rodziny bardzo często nie znają języka kraju przyjmującego - $\mathrm{i}$ jest to pierwsza i najważniejsza bariera, jaką napotykają po przyjeździe. Dodatkowo na problemy językowe nakłada się nieznajomość kultury i zwyczajów, co dodatkowo utrudnia społeczną integrację. Rodziny cudzoziemskie oprócz inności językowej i kulturowej muszą borykać się ze stereotypami i uprzedzeniami społecznymi oraz ograniczonym dostępem do dóbr cywilizacyjnych (edukacja, opieka medyczna), które dodatkowo hamują proces integracji i asymilacji [Błeszyński, 2010: 107-122]. Osobnym problemem utrudniającym funkcjonowanie dzieci w systemie edukacji są problemy bytowe rodziców - mieszkaniowe, socjalne i zarobkowe [Gmaj i in., 2013: 94-95].

Można jednak zauważyć, że pomimo stosownych zapisów legislacyjnych nie jest łatwo wprowadzić uregulowania prawne w życie i do praktyki edukacyjnej. Analizując prawo oświatowe, można odnaleźć stosowne zapisy w Ustawie o systemie oświaty z 7 września 1991 roku, które gwarantują dzieciom migranckim prawo do dodatkowej darmowej nauki języka polskiego, dodatkowych bezpłatnych zajęć wyrównawczych w zakresie przedmiotów objętych programem nauczania czy indywidualizacji w zakresie różnic programowych. Jednak w polskim systemie oświaty brakuje spójnego modelu wsparcia (np. na wzór francuski), którym objęte byłyby również rodziny dzieci bez względu na ich status prawny. Brakuje opieki w miejscu zamieszkania i osób będących łącznikami pomiędzy domem a szkołą, osób, które znają kulturę i język rodzin przybywających. Takie działanie jest ważne, gdyż jak pokazuje praktyka edukacyjna, zrozumienie działań szkoły przez rodzinę dziecka stanowi istotny element integracji społecznej.

Jak wynika z badań nad doświadczeniami dzieci migranckich w zakresie językowym w środowisku szkolnym i domowym przeprowadzonych przez Gill Valentine i innych, można zauważyć pewien proces lawirowania pomiędzy dwoma różnymi środowiskami językowymi i kulturowymi: domem a szkołą, które powoduje ciągły proces negocjowania własnej tożsamości. Jak uważają autorki:

[...] język jest praktyką umiejscowioną. Konkretne przestrzenie [dom i szkoła - I.C.] są wytwarzane przez konkretne języki dominujące i posiadają własne normy i wymogi, które regulują praktyki komunikacyjne i kontakty między różnymi postawami językowymi. W ten sposób posługiwanie się danym językiem w różnych kontekstach przestrzennych może określać jednostki jako znajdujące się „,na swoim miejscu” lub „nie na miejscu” i wpływać na ich poczucie przynależności i identyfikacji [Valentine i in., 2010: 154].

Ważnym aspektem jest zaburzona spójność pomiędzy tym, co w szkole, a tym, co w domu. Stąd dla wielu dzieci migranckich człowiek jest tym, co mówi, a to, co mówi, zależy od tego, gdzie się znajduje. Dzieci potrafią płynnie przechodzić 
na inne języki w różnych przestrzeniach po to, by znajdować się „na miejscu”, gdyż mówienie w danym języku daje poczucie tożsamości i spójności. Jak zauważa Neil Thompson, wybór języka może być tak samo ważny jak dobór słów. W takim rozumieniu tożsamość dzieci migranckich jest płynna, zmienia się stale w momencie przemieszczania się pomiędzy różnymi przestrzeniami [Thompson, 2003: 134]. Stąd tożsamość nie jest zakorzeniona w miejscu pochodzenia czy pobytu, ale jest stale dekonstruowana i rekonstruowana w zależności od tego, gdzie się znajduje dziecko. W takiej perspektywie przestrzeniami, które będą w największym stopniu oddziaływały na konstruowanie tożsamości dziecka, będą te miejsca, w których dziecko przebywa najdłużej. Często dziecko musi „,przestawiać" swoje funkcjonowanie i język, którym się posługuje, w zależności od miejsca, w którym się znajduje.

Innymi trudnościami wpływającymi na społeczną akceptację dzieci migranckich jest sytuacja materialna rodziny, zawodowy czy społeczny status rodziców. Zdarza się, że dziecko jest rozdzielone z jednym z rodziców, który został w kraju pochodzenia. Bardzo często rodziny migrujące pozostawiają za sobą dorobek swojego życia i stąd pojawiają się trudności materialne oraz zależność od systemu socjalnego wsparcia kraju przyjmującego. Ważnym obszarem jest również sytuacja mieszkaniowa dzieci migranckich i ich rodzin. Problemy dotyczą szczególnie dzieci zamieszkujących ośrodki dla uchodźców, instytucje skrajnie segregacyjne, w których dzieci i ich rodziny nie mają szans na pełną integrację społeczną. Taka sytuacja wymaga od systemu edukacji szczególnej wrażliwości i jednostkowego podejścia do każdego dziecka, objęcia wsparciem całej jego rodziny, ale najważniejsze wydaje się opracowanie interdyscyplinarnych modeli wsparcia w edukacji grup szczególnie zagrożonych wykluczeniem. Badacze wskazują też na problem dostępności mieszkań socjalnych, wysokość zasiłków i/lub zarobków oraz dostępność do darmowej nauki języka polskiego. Te utrudnienia i przeszkody mogą zwiększać prawdopodobieństwo wystąpienia takich negatywnych konsekwencji jak brak stałego miejsca zamieszkania, żebractwo i wiele innych [Gmaj, Iglicka, Walczak, 2013].

Przygotowując strategie zarzadzania różnorodnością w szkole, dyrektor musi ująć trzy główne obszary: prawny, gwarantujący skuteczną integrację dzieci migranckich w środowisku szkolnym; finansowy, gwarantujący niezbędne środki do przeprowadzenia działań włączających; oraz najistotniejszy naszym zdaniem aspekt społeczny, włączający tak dziecko, jak jego rodzinę do życia społeczności lokalnej. W tej perspektywie można wskazać na dwa główne obszary zagrażające sprawnemu wdrożeniu modelu zarzadzania różnorodnością w szkole. Pierwszym z obszarów mogą być kwestie organizacyjne, wymagające zaangażowania zarówno środowiska nauczycieli i dyrektorów szkół, jak i środowiska lokalnego (przychodnia zdrowia, ośrodek pomocy społecznej, poradnia psychologiczno-pedagogiczna). Jak pisze Katarzyna Kubin, do tej grupy działań należeć będzie nauka przedmiotów w sytuacji, gdy w klasie uczą się dzieci nieznające języka polskiego, udzielenie wsparcia dzieciom, które nigdy nie uczęszczały do szkoły, udzielenie opieki psychologicznej i często również medycznej. Koniecznie jest także udzielenie wsparcia rodzinie dziecka niemówiącej często w języku kraju 
przyjmującego, zdefiniowanie norm i wartości, różnic religijnych i kulturowych. Różnice te mogą stać się bowiem potencjalnym źródłem stresu [Kubin, 2010: 13].

Z kolei w wymiarze systemowym pojawia się pilna potrzeba dostosowania i uaktualnienia rozwiązań legislacyjnych do zmieniających się warunków społecznych. Katarzyna Kubin wskazuje konieczność poprawy prawa oświatowego w zakresie sposobu przypisywania uczniów do klas, systemu oceny postępów w nauce uczniów nieznających języka polskiego czy z trudnościami w uczeniu się [Kubin, 2010: 14]. Niezwykle znamienny jest fakt, że dzieci z rodzin migranckich praktycznie nie uczestniczą w systemie szkół specjalnych, rzadko też są kierowane do poradni psychologiczno-pedagogicznych [Gmaj i in., 2013]. Warto dodać, że pełna diagnostyka dziecka niemówiącego/nierozumiejącego biegle w języku polskim jest znacznie utrudniona. Warto wtedy skupić się na testach wykonaniowych i niewerbalnych - mamy jednak wtedy do czynienia z diagnozą okrojoną jedynie do pewnych obszarów funkcjonowania. W przypadku diagnozy dzieci migranckich warto pamiętać, że narzędzia diagnostyczne powinny być neutralne kulturowo [Barzykowski i in., 2013: 27-47]. W 2014 roku Zarząd Ogólnopolskiej Sekcji Diagnozy Psychologicznej Polskiego Towarzystwa Psychologicznego uchwalił standardy postępowania diagnostycznego w sytuacji wielokulturowości i stworzył rekomendacje ułatwiające pracę psychologia w zakresie terapii i diagnozy uchodźcy przy braku wystandaryzowanych narzędzi psychologicznych dla różnych grup wiekowych.

Niezwykle istotne jest podkreślenie wspólnego wysiłku całej społeczności szkolnej i lokalnej dla pełnej integracji. Andrew Gitlin i inni trafnie kładą w swoich analizach nacisk na całą społeczność lokalną, a nie tylko szkolną. Wskazali oni na główne obawy wynikające z procesu włączenia, podkreślali, że

\footnotetext{
proces marginalizacji motywowany jest kilkoma czynnikami, takimi jak między innymi: obawa nauczycieli, że będą mieli więcej obowiązków, obawy rdzennych członków społeczności o utratę swoich pozycji, obawy szkoły, iż manifestowanie odmienności może zaburzać procesy asymilacji (por. przykład sprawy chust we Francji), stąd należy wyeliminować takie zachowania, i wreszcie obawy rodziców uczniów imigranckich, że protestując przeciwko asymilacji pozbawią siebie i swoje dzieci korzystnych skutków edukacji [Gitlin i in., 2010: 251].
}

Wynika stąd, że grupy zaangażowane w pracę z uczniami z rodzin migracyjnych mogą być zainteresowane utrzymaniem status quo, które wynika z ich pozycji uprzywilejowania (nauczyciele, rdzenni mieszkańcy) i ich dostępu do władzy. Również po stronie rodzin migranckich część $\mathrm{z}$ nich może być zainteresowana podtrzymywaniem swojej zmarginalizowanej pozycji, choćby ze względów socjalnych.

Odwołując się do badań przeprowadzonych na gruncie polskim, warto podkreślić ich kompleksowość: badani byli dyrektorzy, nauczyciele i rodzice [Błeszyński, 2010; Gmaj i in., 2013]. W obu badaniach przebadani dyrektorzy szkół ocenili przyjęci dzieci migranckich jako szanse rozwoju dla dziecka oraz społeczności szkolnej. Wskazywali oni na problemy związane z izolowaniem się dzieci migranckich, zachowaniami ksenofobicznymi rówieśników oraz problemami 
komunikacyjnymi na linii szkoła-dziecko-rodzina. Swoje zadania postrzegali na poziomie organizacyjnym oraz akulturacyjnym. Słabo oceniali dostęp dzieci i ich rodzin do poradni psychologiczno-pedagogicznych, służby zdrowia, pomocy społecznej oraz organizacji pozarządowych (sic!). 50\% badanych dyrektorów uważało, że szkoły polskie nie są dobrze przygotowane do uczenia dzieci migranckich [Gmaj i in., 2013: 25-47]. Nauczyciele uczący dzieci migranckie bardzo często zgłaszali potrzebę edukacji kulturowej, aby lepiej rozumieć dziecko [Błeszyński, 2010: 80-95]. W swoich działaniach skupiali się głównie na edukacji, a nie na budowaniu więzi i komunikacji w klasie/szkole. Z badań wynika, że często brakowało im pomysłów na integrację i przełamywanie barier, skupiali się głównie na indywidualnej pracy z dzieckiem. Głęboki niepokój budzą znikome kontakty z rodziną dziecka migranckiego. Nauczyciele bardziej koncentrowali się na barierach organizacyjnych, wychowawczych i komunikacyjnych niż na potencjalnie pozytywnych aspektach inkulturacji. Pytani o źródła problemów z integracją klasy, wskazywali raczej na postawy izolacyjne migrantów oraz ich słabą znajomość języka [Gmaj i in., 2013: 48-81]. Za to bardzo aktywną grupą wparcia byli psychologowie i pedagodzy szkolni: utrzymywali stałe kontakty z rodzinami dzieci migranckich, realizowali inicjatywy integracyjne oraz włączali społeczność lokalną w swoje działania [Gmaj i in., 2013: 81-86; Błeszyński, 2010: 80-95].

W tej sytuacji, tworząc programy włączające, należy wyjść od uświadomienia wszystkim uczestnikom tego procesu potrzeby zmiany. Nie wystarczą treningi i szkolenia dla kadry dydaktycznej, ale należy włączyć całą społeczność lokalną. W polskim systemie oświaty bardzo często nacisk jest położony właśnie na szkolenia wydelegowanych przez dyrektora nauczycieli (lub takich, którzy sami interesują się tym zagadnieniem, mają w swoich klasach uczniów migranckich i nie wiedzą, jak z nimi pracować), z pominięciem całej struktury organizacyjnej i systemowej. Brakuje również tutoringu włączającego do sieci wsparcia w integracji rodzin, innych uczniów i nauczycieli, administracji, przedsiębiorców i pracowników jednostek samorządu lokalnego tworzących szeroko rozumiane społeczeństwo lokalne. Jak wskazuje Jan Fazlagić, jednym z podstawowych czynników uzyskiwania wysokich efektów edukacyjnych w szkole jest proces dzielenia się wiedzą zarówno nauczycieli, jak i uczniów. Ważną rolę odgrywa tu dialog, który toczy się między uczestnikami. Szczególnie istotne jest stworzenie odpowiedniej dla dialogu atmosfery życzliwości i zaufania oraz odpowiedniego motywowania do tego niełatwego przecież procesu [Fazlagić, 2014a: 128].

\section{Rekomendacje dla praktyki edukacyjnej}

Istotne we wdrażaniu programów włączających dla uczniów migranckich jest wyłonienie lidera, czyli osoby lub osób odpowiedzialnych za ten proces, najlepiej osób znaczących w swoich społecznościach, zdolnych zaangażować wielu ludzi i instytucji. Ważne, by lider (często jest nim dyrektor szkoły, w której uczą się dzieci z rodzin migranckich) miał przynajmniej podstawową wiedzę i umiejętności zarządzania zróżnicowanym środowiskiem. Obecnie zarzadzanie 
różnorodnością, a tym samym wielokulturowością, obejmuje aspekty społeczno-kulturowe, takie jak płeć, wiek, orientacja seksualna, rasa czy pochodzenie etniczne, grupa zawodowa, doświadczenie, wykształcenie, kwalifikacje, stopień sprawności [Robbins, DeCenzo, 2002: 106]. Takie rozumienie daje dyrektorowi/ liderowi pełen wachlarz działań i szeroką perspektywę włączania. Im większa jest różnorodność kulturowa w danej organizacji czy szkole, tym trudniej stworzyć w niej społeczność spójną, o spójnej tożsamości, tym trudniej również stworzyć jedną spójną kulturę (metakulturę). Stąd niezwykle istotne jest włączanie poprzez działania na różnych polach (szkoła, dom, grupy rówieśnicze, grupy wsparcia, ośrodki pomocowe, poradnie pedagogiczno-psychologiczne, NGOs czy rynek pracy).

Zarządzaniem różnorodnością możemy więc określić działania, które ukierunkowane są na dostrzeganie i akceptację różnic i wykorzystywanie ich jako potencjału dla swojej organizacji czy środowiska życia. W zarządzaniu różnorodnością J. Fazlagić podkreśla niezwykle istotny aspekt szacunku i wrażliwości dla różnorodności, który utrzymuje środowisko przyjazne dla wszystkich [Fazlagić, 2014b: 54]. Bardzo ważny jest głos Ricky’ego W. Griffina, który podkreśla, że zarządzanie różnorodnością można przeprowadzić, tylko traktując je komplementarnie, z włączeniem wymiaru indywidualnego i organizacyjno-systemowego. Wymienia on podstawowe postawy, które należy przyjąć w organizacji:

- zrozumienie, czyli akceptacja dla zróżnicowanych zachowań;

- empatia, czyli umiejętność wczuwania się w stan drugiej osoby i współodczuwania;

- tolerancja, czyli zdolność do szacunku wobec innych poglądów i systemów wartości;

- komunikacja, która jest niezbędnym warunkiem rozwiązywania trudności wynikających z różnorodności; jak uważa R. Griffin, tylko spokojna rozmowa i dyskusja zapobiegają często eskalacji konfliktów [Griffin, 2013: 195].

W sytuacji wdrażania w życie szkoły programów wspierających zarządzanie różnorodnością warto odwołać się do Karty Różnorodności, czyli międzynarodowego narzędzia, które reguluje kwestie związane z równym traktowaniem przy włączeniu wszystkich interesariuszy szkół i organizacji, które do niej przystępują [Kancelaria Prezesa Rady Ministrów, 2012]. Karta zakłada promocję różnorodności oraz - co niezwykle istotne - zakaz dyskryminacji ${ }^{2}$. Inicjatywa stworzenia polskiej wersji Karty Różnorodności powstała podczas spotkania przedstawicieli firm z francuskim kapitałem w maju 2011 roku, a jej inauguracja miała miejsce 14 lutego 2012 roku podczas konferencji w Kancelarii Prezesa Rady Ministrów. Karta Różnorodności w Polsce objęta jest honorowym patronatem Rzecznika Praw Obywatelskich.

Poza ogólnymi wytycznymi o równym dostępie do edukacji i integracji społecznej warto wskazać na najistotniejsze elementy pracy z klasami wielokulturowymi. Warto, by nauczyciel pracujący z klasą wielokulturową był do tego zadania

${ }^{2}$ Więcej na temat Karty Różnorodności na stronie: http://odpowiedzialnybiznes.pl/karta-roznorodnosci/ [dostęp: 22.07.2017]. 
odpowiednio przygotowany. Podobnie jak w modelu francuskim (wspomnianym wcześniej), nauczyciel powinien znać kulturę, obyczaje kraju pochodzenia swoich uczniów, jednak powinien być również świadomy swojej tożsamości kulturowej. Nie można pominąć faktu, że uczniowie również postrzegają nauczyciela zgodnie ze swoimi przekonaniami warunkowanymi społecznie i kulturowo. Nie chodzi o to, by nauczyciel stał się neutralny kulturowo, ale by wyrażał akceptację dla różnorodności swojej i uczniów w swojej klasie. Z kolei znajomość kultury czy religii swoich uczniów ułatwia zrozumienie i akceptację czasami różnych zachowań, ale też z pewnością kontakty z rodzicami dziecka. Bardzo ważną kwestią, którą musi podjąć nauczyciel, jest akceptacja uczniów takimi, jakimi są, z całym ich bagażem często trudnych doświadczeń. Sytuacja migrantów prawie zawsze jest złożona i trudna. Na tę sytuację składają się trudności materialne, które mogą silnie oddziaływać na procesy integracji społecznej, wręcz utrudniają ją, doprowadzając do automarginalizacji dzieci ze środowiska szkolnego i społeczności lokalnej [Derek Bok Center..., 2002-2006: 3-4]. Stąd bardzo ważne jest poznanie życia swoich uczniów przez nauczyciela, poznanie rodziny, jej trosk i radości. Z pewnością będzie to łatwiejsze dla nauczycieli z mniejszych szkół, jednak nie jest niemożliwe w dużych szkołach. Można w sposób niestandardowy prowadzić zebrania z rodzicami, z rozmową przy kawie i dobrych ciastkach, w luźnej atmosferze, wokół ciekawych tematów.

Inną istotną kwestią jest przygotowanie odpowiednich metod i pomocy dydaktycznych bazujących na tematyce różnych kultur, przybliżanie różnych kultur poprzez ciekawe spotkania z przedstawicielami innych kultur i religii, omawianie przypadków znanych osób, które reprezentują różne społeczności (jednym z najbardziej znanych muzułmanów we Francji jest Zinédine Zidane - $\mathrm{i}$ to jego przykład jest często omawiany w trakcie zajęć o tematyce społeczeństwa obywatelskiego). Rekomenduje się, by zajęcia rozpocząć od zawarcia kontraktu, w którym ustalone zostaną zasady aktywności, wzajemnego szacunku i tolerancji dla odmienności każdego z uczniów. Uczniom, którzy z różnych względów unikają wypowiedzi, nauczyciel powinien zapewnić taką możliwość, choćby poprzez odwołanie się do kontraktu czy zadawanie spersonalizowanych pytań. Warto również na zajęciach poruszać aktualne tematy z życia społecznego na świecie, nie bać się dyskusji. Ważne w tym miejscu jest unikanie stereotypów i uprzedzeń w dyskusjach. Należy też pamiętać, by nie stawiać uczniów w sytuacji odpowiedzialności za całą grupę społeczną [Derek Bok Center..., 2002-2006: 6-7]. Sytuacje dyskusji nad trudnymi sprawami mogą generować konflikty. Nauczyciel powinien być przygotowany na takie sytuacje i przed każdymi zajęciami przygotować scenariusz, który pozwoli wychwycić sytuacje potencjalnie konfliktowe i odpowiednio się do nich przygotować (np. przez pokazanie wyników badań naukowych czy prezentację filmu). Koniecznie przed każdymi zajęciami należy przywołać kontrakt zawarty przez wszystkie strony. 
Praca z uczniem migrantem powinna w polskiej szkole przebiegać wielotorowo: poza nauką języka i kompensacją braków programowych ważne jest budowanie więzi między dziećmi polskimi i cudzoziemskimi poprzez różnorodne działania formalne i nieformalne na poziomie klasy, szkoły, społeczności, mające na celu większą integrację. Bardzo ważnym zadaniem szkoły jest budowanie klimatu współpracy, otwartości w relacjach z rodziną migrancką oraz społecznością lokalną, po to, by wspólnie tworzyć klimat sprzyjający różnorodności kulturowej.

\section{Bibliografia}

Barzykowski K., Grzymała-Moszczyńska H., Dzida D., Grzymała-Moszczyńska J., Kosno M. (2013), Wybrane zagadnienia diagnozy psychologicznej dzieci i młodzieży w kontekście wielokulturowości i wielojęzyczności, MEN, ORE, Warszawa.

Błeszyński K.M. (2010), Dzieci obcokrajowców w polskich placówkach oświatowych - perspektywa szkoły. Raport z badań, Ośrodek Rozwoju Edukacji, Warszawa.

Derek Bok Center for Teaching and Learning, Harvard University (2002-2006), Teaching in Racially Diverse College Classrooms, by the President and Fellows of Harvard College, http://www.ccsu.edu/ddesignation/files/Race_and_the_Classroom.docx [dostęp: 25.07.2017].

Fazlagić J. (2014a), Innowacyjne zarzadzanie wiedza, Wydawnictwo Difin, Warszawa.

Fazlagić J. (2014b), Zarządzanie różnorodnością a zarządzanie wiedzą, „e-mentor”, 1(53).

Gitlin A., Buendia E., Crosland K., Doumbia F. (2010), Tworzenie centrum marginesu - wtaczanie i wykluczanie uczniów imigranckich [w:] A. Grudzińska, K. Kubin (red.), Szkota wielokulturowa - organizacja pracy i metody nauczania. Wybór tekstów, Fundacja na Rzecz Różnorodności Społecznej, Warszawa.

Gmaj K., Iglicka K., Walczak B. (2013), Dzieci uchodźcze w polskiej szkole, Wydawnictwo Naukowe Scholar, Warszawa.

Griffin R.W. (2013), Podstawy zarządzania organizacjami, tłum. M. Rusiński, Wydawnictwo Naukowe PWN, Warszawa.

Kancelaria Prezesa Rady Ministrów (2012), Karta Różnorodności, https://www.rpo.gov.pl/sites/default/files/13292263690.pdf [dostęp: 22.07.2017].

Kubin K. (2010), Wprowadzenie [w:] A. Grudzińska, K. Kubin (red.), Szkoła wielokulturowaorganizacja pracy i metody nauczania. Wybór tekstów, Fundacja na Rzecz Różnorodności Społecznej, Warszawa.

Preambuła Ustawy z dnia 7 września 1991 r. o systemie oświaty, http://prawo.sejm.gov.pl/ isap.nsf/DocDetails.xsp?id=WDU19910950425 [dostęp: 20.07.2017].

Robbins S.P., DeCenzo D.A. (2002), Podstawy zarządzania, tłum. A. Ehrlich, Polskie Wydawnictwo Ekonomiczne, Warszawa.

Rosado C. (2006), What Do We Mean by „,Managing Diversity”, EdChange and the Multicultural Pavilion ICAFAI University, Hyderabad, India.

Silver H. (1995), Reconceptualizing Social Disadvantage: Three Paradigms of Social Exclusion [w:] G. Rogers, Ch. Gore, J.B. Figueiredo (eds.), Social Exclusion: Rhetoric Reality 
Responses, International Institute for Labour Studies, International Labour Organization, Genewa.

Szarfenberg R. (2007), Ubóstwo, marginalność i wykluczenie społeczne [w:] G. Firlit-Fesnak, M. Szylko-Skoczny (red.), Polityka społeczna, Wydawnictwo Naukowe PWN, Warszawa. Thompson N. (2003), Promoting Equality: Challenging Discrimination and Oppression in Human Services, Palgrave Macmillan Press, Basingstoke.

Valentine G., Sporton D., Nielsen K. (2010), Migracja a posługiwanie się językiem: miejsca spotkań, tożsamości i przynależności [w:] A. Grudzińska, K. Kubin (red.), Szkoła wielokulturowa-organizacja pracy i metody nauczania. Wybór tekstów, Fundacja na Rzecz Różnorodności Społecznej, Warszawa.

Zachorowska-Mazurkiewicz A. (2007), Społeczeństwo wiedzy. Instytucjonalna analiza czynników promujacych nowy model społeczny [w:] K. Piecha, E. Skrzypek (red.), Wiedza $w$ gospodarce, społeczeństwie i przedsiębiorstwach: pomiary, charakterystyka, zarzadzanie, Instytut Wiedzy i Innowacji, Warszawa.

Zarząd Ogólnopolskiej Sekcji Diagnozy Psychologicznej Polskiego Towarzystwa Psychologicznego (2014), Wskazówki realizacji standardów ogólnych prowadzenia procesu diagnostycznego $w$ sprawach osób ubiegających się o nadanie statusu uchodźcy $w$ Polsce, https:/diagnozowanieuchodzcow.wordpress.com/standardy-postepowania-diagnostycznego-wsp-uchodzcow/ [dostęp: 25.07.2017]. 